\title{
Transformasi Tari Bedana Tradisi Menjadi Tari Kreasi
}

\author{
Oleh: \\ Riyan Hidayatullah ${ }^{1)}$, Indra Bulan ${ }^{2)}$ \\ FKIP, Universitas Lampung \\ Email: riyan.1002@fkip.unila.ac.id
}

\begin{abstract}
Bedana Dance is one of Lampungnese traditional arts. This dance was brought by the Arabs in 1930 who later taught it to three children named Ma'ruf, Amang, and Abdullah. They then spread this dance to all corners of Lampung. Bedana Dance is a traditional dance that has its roots and is perceived as a symbol of a very wide tradition about the view of life as well as a friendly and open environment. In time, it is assumed the bedana dance has undergone a fairly strong transformation. This dance has evolved into bedana dance creations. There is a change in the formation of dancers who are group, in addition to the dance of the bedana has also been danced in traditional events and other entertainment events. In this study, descriptive method is used to find and describe the form of motion danana dance and the meaning of motion dance traditional dress become creations. This new dance is famous for the term new dance creations. Similarly with Bedana Dance, where the dance was originally a traditional dance, but as many developed so that the models and equipment used in dance bedana also experienced a change.
\end{abstract}

Keywords: Dance of creations, dance transformation, Lampung

Abstrak. Tari Bedana adalah salah satu kesenian tradisional masyarakat Lampung. Tari ini dibawa oleh orang Arab pada sekitar tahun 1930 yang kemudian diajarkan kepada tiga orang anaknya bernama Ma'ruf, Amang, dan Abdullah. Mereka lalu menyebarkan tarian ini ke seluruh pelosok daerah Lampung. Tari Bedana adalah tari tradisional yang telah berakar serta dirasakan sebagai suatu simbol tradisi yang sangat luas tentang pandangan hidup serta alam lingkungan yang ramah dan terbuka. Seiring dengan semakin berkembangnya waktu dan pemahaman masyarakat akan tarian bedana, sehingga saat ini diasumsikan tari bedana telah mengalami transformasi yang cukup kuat. Tari bedana tradisi telah berkembang menjadi tari bedana kreasi. Terlihat adanya perubahan formasi penari yang bersifat kelompok, selain itu tari bedana juga telah dapat ditarikan dalam acara adat maupun acara hiburan lainnya. Dalam penelitian ini, metode deskriptif digunakan untuk mengetahui dan mendeskripsikan bentuk gerak tari bedana dan makna gerak tari bedana tradisi menjadi kreasi. Tarian baru ini terkenal dengan istilah tari kreasi baru. Begitupula dengan Tari Bedana, dimana tarian ini awalnya merupakan tari tradisional, namun seiring banyak yang mengembangkan sehingga model dan perlengkapan yang digunakan dalam tari bedana juga mengalami perubahan.

Kata kunci: Tari bedana kreasi, Transformasi tari, Lampung 


\section{PENDAHULUAN}

Seni tari adalah keindahan ekspresi jiwa manusia yang diungkapkan dalam bentuk gerak tubuh yang diperhalus dengan estetika (Mustika, 2012:21). Sebuah seni tarian menuntut kecermatan dan kesempurnaan yang dibebankan kepada seorang penari dalam melakukan sebuah gerakan. Jadi, penari harus mapan dalam penguasaan materi dan penjiwaan maknanya (Nusantara, 2007:106). Dalam hal ini tari berarti mengandung arti perpaduan gerakan-gerakan indah dan ritmis yang disusun atau ditata sehingga dapat memberi kesenangan dan kepuasan bagi pelaku dan penikmatnya (Firmansyah dkk, 1996:2).

Daerah Lampung memiliki beraneka ragam tari tradisional sebagai cermin kehidupan masyarakat Lampung yang harus dipelihara dan dikembangkan, salah satunya adalah tari bedana. Tari bedana merupakan tari tradisional kerakyatan daerah Lampung yang mencerminkan tata kehidupan masyarakat Lampung sebagai perwujudan simbolis adat istiadat, agama, etika yang telah menyatu dan kehidupan masyarakat. Menurut sejarah, konon kabar tari Bedana ini hidup dan berkembang di daerah Lampung seiring dengan masuknya agama islam.

Tari Bedana hidup dan berkembang di daerah Lampung seiring dengan masuknya agama Islam. Pada mulanya Tari Bedana ditarikan oleh laki-laki secara berpasangan atau kelompok dan hanya dapat disaksikan oleh keluarga saja. Tari Bedana ditarikan pada saat anggota keluarga hatam Al-Quran. Melalui perkembangan zaman sekarang Tari bedana dapat ditarikan oleh laki-laki perempuan secara berpasangan ataupun perempuan saja dan dapat disaksikan oleh masyarakat umum. Menurut Endri Y., Ketua Seni Budaya PW Pemuda Muhammadiyah Provinsi Lampung Tari Bedana adalah salah satu kesenian tradisional masysrakat Lampung. Tari ini dibawa oleh orang Arab pada sekitar tahun 1930 yang kemudian diajarkan kepada tiga orang anaknya bernama Ma'ruf, Amang, dan Abdullah. Mereka lalu menyebarkan tarian ini ke seluruh pelosok daerah Lampung. Tari Bedana adalah tari tradisional yang telah berakar serta dirasakan sebagai suatu simbol tradisi yang sangat luas tentang pandangan hidup serta alam lingkungan yang ramah dan terbuka.

Tari Bedana adalah sebuah kesenian rakyat yang bernafaskan Islam, mencerminkan tata kehidupan masyarakat Lampung yang ramah dan terbuka sebagai simbol persahabatan dan pergaulan anak muda Lampung dengan komitmen beragama. Tari bedana juga merupakan salah satu nilai budaya untuk mengintrospeksikan suatu 
pergaulan, kasih sayang, dan persaudaraan, yang tulus dan ikhlas sebagai ciri dari sebuah ketradisionalan yang tak akan lepas. Tari ini ditampilkan secara berpasangan, sebaiknya putra dan putri. Satu keunikan bernilai plus dari tari berpasangan ini adalah bahwa ragam gerak tari bedana tidak memperkenankan penari bersentuhan dengan pasangannya. Hal itu merupakan refleksi sebuah pergaulan masyarakat dan muda-mudi yang harus penuh kehati-hatian dan saling menjaga kehormatan diri untuk tidak bersentuhan dengan orang yang bukan mahramnya. Filosofi tersebut tidaklah mustahil ada, sebab tari Bedana ini memang dibawa oleh orang Arab yang memiliki budaya demikian.

Tari bedana sebagai salah satu jenis tari tradisional Lampung merupakan pewujudan simbolis dari adat istiadat dan agama dan telah menyatu dengan masyarakat Lampung. Menurut sejarah tari bedana hidup dan berkembang di daerah Lampung seiring dengan masuknya agama islam, sehingga tidak mengherankan jika di daerah lain di Indonesia memiliki kesamaan baik ragam maupun geraknya, yang memiliki fungsi yang sama pula, yaitu tari pergaulan (Firmansyah, 1996:3).

Seiring dengan semakin berkembangnya waktu dan pemahaman masyarakat akan tarian bedana, sehingga saat ini diasumsikan tari bedana telah mengalami transformasi yang cukup kuat. Tari bedana tradisi telah berkembang menjadi tari bedana kreasi. Tari tersebut merupakan tari pergaulan yang bisa disajikan tunggal, berpasangan, atau kelompok dengan menggunakan properti yang digunakan dalam berbagai acara. Tari Bedana yang tadinya ditarikan berpasangan pada masa sekarang ini hanya ditarikan secara kelompok dengan tambahan properti kipas hal ini membuat tarian bedana menjadi lebih menarik dan lebih bebas tidak terikat dengan nilai-nilai tradisi Dahulu tari ini merupakan tarian yang hanya disajikan untuk upacara adat sakral yang hanya ditarikan oleh penari yang ditentukan oleh tetua adat setempat, serta hanaya dapat ditampilkan ditempat tertentu. Tari Bedana merupakan tarian sakral yang hanya diadakan pada acara hatam qur'an tapi pada masa sekarang ini Tari Bedana dapat ditampilkan dimana saja kapan saja tanpa harus terikat dengan norma-norma adat.

Berdasarkan asumsi yang telah berkembang ditengah masyarakat diatas maka diyakini saat ini tari bedana telah mengalami proses transformasi yang cukup kuat. Namun perubahan yang terjadi saat ini dalam tubuh tari bedana belum dapat dideskripsikan secara rinci mengingat belum ada penelitian yang mempetakan perubahan-perubahan yang terjadi dalam tari bedana tersebut. Oleh karenanya penelitian ini akan 
mendeskripsikan dan menganalisis lebih dalam transformasi yang terjadi dalam tari bedana. Tujuan penelitian ini adalah untuk mendeskripsikan dan menganalisis bentuk transformasi tari bedana tradisional menjadi tari bedana kreasi.

\section{LANDASAN TEORI}

Adapun paparan teori-teori yang dipinjam sebagai 'pisau analisis' untuk membedah pokok bahasan dalam penelitian ini adalah sebagai berikut:

1. Teori Transformasi

Istilah "transformasi" sangat erat dengan "perubahan", yakni perubahan terhadap suatu hal atau keadaan. Dalam sebuah teks karya seni selalu mengalami perubahan sebesar atau sekecil apa pun itu, seperti yang telah disebut di atas bahwa makna kunci dari transformasi adalah perubahan. Sebuah karya tari yang dipertunjukkan pada satu bentuk $^{1}$, kemudian kembali dipertunjukkan dengan bentuk yang sama, tentu akan mengalami perubahan. ${ }^{2}$ Artinya meskipun dalam bentuk yang sama, namun jika dipertunjukkan pada waktu yang berbeda akan terjadi perubahan.

Dalam hal teks tari bedana, dengan bentuk yang sama yakni dalam wadah tarian, kemudian mungkin sebagai upaya eksistensi diri dan perkembangan waktu mengalami perubahan bentuk. Perubahan yang terjadi mungkin dipengaruhi oleh lingkungan sosial, yang merupakan bagian dari perubahan kebudayaan. Dalam masyarakat suatu proses perubahan terdapat faktor-faktor yang mempengaruhi perubahan tersebut terjadi. Perubahan tari bedana menjadi tari bedana kreasi dipengaruhi oleh perubahan sosial yang berkaitan juga dengan perubahan budaya, khususnya keberadaan tari bedana itu sendiri.

Untuk mengetahui bagaimana pola perubahan yang terjadi dan apa saja yang mengalami perubahan dalam tari bedana bisa dilihat dari unsur interaksi manusia, suasana lingkungan, dan kebutuhan hidup manusia itu sendiri. Terkait dengan perubahan tari bedana tradisional menjadi tari bedana kreasi, transformasi diartikan 
sebagai perubahan bentuk yang terjadi akan dianalisis dengan teori bentuk meliputi perubahan gerak, busana, musik, dan lain sebagainya.

\section{Teori Bentuk}

Hadi dalam bukunya tentang 'kajian tari teks dan konteks' merumuskan bentuk sebagai wujud yang diartikan hasil dari berbagai elemen tari yaitu gerak, ruang dan waktu. Elemen-elemen itu bersama-sama bersatu mencapai vitalitas estetis. Proses penyatuan itu mendapatkan bentuk yang disebut sebagai komposisi tari atau koreografi (Hadi, 2007). Dengan teori koreografi diungkapkan bentuk gerak, teknik gerak, dan gaya gerak pada tari melinting sebagai seni pertunjukan.

Pemahaman bentuk gerak meliputi kesatuan, variasi, repetisi, transisi, rangkaian, perbandingan, dan klimaks. Teknik gerak dipahami sebagai cara mengerjakan seluruh proses, baik fisik maupun mental, dalam mewujudkan pengalaman estetis sebuah komposisi tari. Gaya gerak lebih mengarah pada konteks ciri khas atau corak yang terdapat pada bentuk dan teknik gerak. Gaya gerak tersebut, menyangkut pembawaan pribadi maupun ciri sosial-budaya yang melatarbelakangi bentuk dan teknik dalam Tari Bedana.

Analisis bentuk dikenal juga sebagai telaah struktural yang memandang fenomena gerak atau tari sebagai fenomena bahasa. Tari pada dasarnya adalah ekspresi, perwujudan yang berupa simbol-simbol dari perasaan manusia yang ingin dikomunikasikan kepada orang lain. Tari merupakan subjektivitas seniman pembuatnya, sehingga perlu dipahami tentang sistem dan aturan yang berlaku. Hal tersebut perlu dilakukan pada beberapa simbol dalam gerak tari agar dapat ditangkap arti dan maknanya. Unsur utama yang paling pokok dalam tari adalah gerak tubuh manusia. Tari merupakan keindahan ekspresi jiwa manusia yang diungkapkan berbentuk gerak tubuh yang diperhalus melalui estetika. Tari adalah ekspresi jiwa manusia yang diubah oleh imajinasi dan diberi bentuk melalui media gerak, sehingga menjadi bentuk gerak yang simbolis dan sebagai ungkapan pencipta tarian tersebut (Hawkins: 1990:2). Tari adalah gerak-gerak ritmis baik sebagian atau seluruh anggota tubuh yang terdiri dari pola individu atau kelompok yang disertai oleh ekspresi atau ide tertentu (Tim, 1996:5). Tari merupakan perpaduan pola-pola di dalam ruang yang disusun dan dijalin menurut aturan pengisian waktu tertentu (Junaidi, 1996:5). Dari beberapa pendapat ahli di atas, dapat disimpulkan bahwa tari merupakan ekspresi jiwa 
manusia sesuai dengan motivasi tertentu, yang diungkapkan lewat gerak-gerak yang indah dan ritmis.

\section{METODE PENELITIAN}

\section{Desain Penelitian}

Desain penelitian yang digunakan dalam penelitian ini adalah deskriptif. Metode deskriptif adalah metode yang menggambarkan objek penelitian sesuai dengan apa adanya (Arikunto, 1996:234). Dalam penelitian ini, metode deskriptif digunakan untuk mengetahui dan mendeskripsikan bentuk gerak tari bedana dan makna gerak tari bedana tradisi menjadi kreasi. Data-data yang diperlukan untuk menjawab bagaimana kedua masalah tersebut, maka diperlukan kajian yang lebih mendalam.

\section{Teknik Pengumpulan Data}

Metode pengumpulan data yang digunakan dalam penelitian ini bermacam-macam bentuknya, mulai dari materi, bahasa dan tindakan yang berkaitan dengan tari bedana di Bandar Lampung. Materi yang dimaksudkan adalah sesuatu yang berwujud tulisan tentang tari bedana. Bahasa atau kata-kata dan tindakan merupakan sumber data utama yang bersifat pengamatan dan wawancara berupa melihat, mendengar, bertanya kepada pendekar, pelatih, dan anggota. Sumber data ini dapat dicatat melalui catatan tertulis atau melalui pengambilan foto, rekaman suara, dan video visual recorder saat pementasan dan latihan. Ada bermacam-macam materi berupa sumber data kualitatif yang digunakan yaitu:

a. Observasi

Pengumpulan data melalui observasi dilakukan, untuk mengamati secara langsung apa yang terjadi di lapangan. Dari observasi didapat gambaran tentang bentuk gerak dan makna tari bedana yang berkembang di Bandar Lampung. Dengan mengamati ragam gerak tari, musik, pola lantai, rias dan busana, serta properti yang digunakan. Penyajian ini diabadikan dengan cara pemotretan dan juga rekaman secara audio visual. Hasil pendokumentasian tersebut digunakan sebagai data primer. Usaha pengumpulan data secara observasi dilakukan di wilayah Bandar Lampung, khususnya yang di daerah yang menggunakan tari bedana dalam acara-acaranya. Pencarian data tari bedana di Bandar Lampung khususnya di Taman Budaya dilakukan sesering mungkin untuk mendapat data yang lebih objektif.

b. Wawancara

Data-data yang diperoleh dari narasumber, penting untuk dicatat dan dikaji secara mendalam. Penelusuran data tari bedana yang berkembang saat ini, lebih banyak menggunakan teknik wawancara. Teknik wawancara yang digunakan teknik 
wawancara tidak terstruktur, yaitu peneliti berpedoman pada garis besar permasalahan yang akan ditanyakan (Sugiyono, 2011). Pertanyaan biasanya tidak disusun terlebih dahulu, tetapi pertanyaan akan disesuaikan dengan keadaan dan ciri unik responden (Moleong, 2007). Narasumber yang dipilih adalah yang mengetahui secara pasti dan terlibat langsung dalam kegiatan, serta wawancara dengan beberapa narasumber yang dianggap penting dalam kajian ini. Hasil yang diperoleh data informasi tentang tari bedana sesuai dengan apa yang ditanyakan, dokumentasi gambar, rekaman hasil wawancara, dan data pendukung lainnya.

c. Studi Pustaka

Penelaahan kepustakaan merupakan studi awal, guna mendapatkan informasi secara tertulis dengan melakukan pengumpulan dan mempelajari beberapa referensi. Referensi dapat diperoleh dari data-data tertulis berupa buku-buku, laporan penelitian, artikel, manuskrip, majalah, dan surat kabar yang berkaitan dengan Tari Bedana. Bukubuku yang dapat dipergunakan sebagai data adalah buku-buku koleksi pribadi yang terkait dengan penelitian, di antaranya buku deskripsi tari bedana dan beberapa buku yang menunjang untuk penelitian ini. Selain itu dilakukan juga tinjauan pustaka melalui penelitian berupa tesis, disertasi dan publikasi ilmiah lainnya.

d. Dokumentasi

Pengumpulan data dilakukan dengan pengumpulan foto-foto dan rekaman audio visual. Data-data tersebut dipergunakan untuk memperkuat bahwa proses penelitian benar-benar telah dilakukan. Selain itu data dokumentasi juga berupa data hasil wawancara yang berupa catatan dan rekaman, serta foto-foto dan gambar yang berkaitan dengan tari bedana.

\section{Teknik Analisis Data}

Hasil pengamatan yang telah diperoleh, yang dimulai dari pengumpulan data, yaitu mengidentifikasikan bentuk pertunjukan Tari bedana pada masa awal. Selanjutnya mengidentifikasikan bentuk pertunjukan Tari bedana yang berkembang saat ini sebagai seni pertunjukan pariwisata. Dilihat dari elemen-elemennya yang banyak mengalami perubahan. Mengidentifikasikan faktor-faktor penyebab perubahan bentuk Tari bedana, yaitu faktor internal dan faktor eksternal. Penyebab perubahan adalah faktor ekonomi, pendidikan, teknologi, komunikasi, dan perubahan nilai budaya masyarakat. Dari faktor-faktor yang telah diuraikan akan mendapatkan suatu kesimpulan mengenai perubahan bentuk pertunjukan Tari bedana. 


\section{PEMBAHASAN}

Proses penyebaran agama islam di indonesia menggunakan berbagai cara. Salah satu metode yang digunakan yakni dengan memanfaatkan kesenian. Pada perkembangannya penyebaran islam seringkali memanfaatkan seni tari, seni bangunan, seni musik, dan seni rupa. Dalam berbagai kegiatan keagaamaan pertunjukan kesenian tersebut tampak dipentaskan atau ditampilkan oleh masyarakat, baik untuk tujuan sebagai hiburan maupun sebagai media pembelajaran islam kepada masyarakat. menurut Hearbert Read seni merupakan usaha penciptaan bentuk-bentuk yang menyenangkan. ${ }^{3}$ Kesenangan-kesenangan yang dimaksud ialah kesenangan dalam estetika. ${ }^{4}$ Di provinsi lampung penyebaran agama islam dengan menggunakan kesenian sangat berkembang dengan baik. Berbagai kesenian hidup dan berkembang di tengah masyarakat. hingga kini kesenian tersebut terus hidup dan dicintai oleh masyarakat. kesenian yang berkembang di lampung yakni Tari Bedana, Hadroh, dan bershawalatan.

Tari bedana merupakan tari tradisional kerakyatan daerah lampung yang mencerminkan tata kehidupan masyarakat lampung sebagai perwujudan simbolis, adat istiadat, agama, etika yang telah menyatu dalam kehidupan masyarakat. ${ }^{5}$ keberadaan Tari Bedana diperkirakan sudah berabad-abad lamanya seiring dengan kedatangan saudagar yang melakukan perdagangan ke lampung pesisir. ${ }^{6}$

Tari bedana sebagai sebuah hasil karya tari tradisional saat ini semakin tergerus dengan zaman modern. Di dunia hiburan, tari tradisional sulit bersaing dengan tari modern. Hal tersebut dapat dimaklumkan mengingat sang penikmat hiburan memiliki selera yang selalu meningkat di setiap waktunya. Sedangkan tari tradisonal tidak dapat mengimbangi dikarenakan masih bersifat sederhana dan monoton atau sebaliknya rumit dan sulit dipahami. Melihat fenomena tersebut, banyak kemudian seniman yang mencoba mengembangkan tari-tari tradisional menjadi tari kreasi yang dapat dinikmati oleh masyarakat. Berbagai upaya pengembangan dilakukan oleh para senimanseniman (penari/koreografer) klasik pada masanya. Terutama ketika kebebasan berpendapat atau berkarya telah dibuka oleh peradaban, maka pergerakan tarian klasik mengalami kemajuan yang sangat pesat. Tarian klasik bukan lagi milik istana, namun 
semua lapisan masyarakat telah bebas untuk memelihara atau bahkan mengembangkan tarian ini. Dari sinilah kemudian lahir karya-karya baru tari klasik yang dikembangkan oleh tokoh- tokoh tari pada waktu itu dengan memberikan tema-tema baru dalam tariannya.

Tarian baru ini terkenal dengan istilah tari kreasi baru. Begitupula dengan Tari Bedana, dimana tarian ini awalnya merupakan tari tradisional, namun seiring banyak yang mengembangkan sehingga model dan perlengkapan yang digunakan dalam tari bedana juga mengalami perubahan. Pada masa sekarang tari bedana ditambahkan menggunakan properti. Properti merupakan alat atau apapun yang dimainkan oleh penari di atas panggung (arena pentas). Kehadiran properti biasanya digunakan untuk membantu memperjelas karakter, peristiwa, ruang, atau bahkan memamerkan ketrampilan teknik dari para penari di atas panggung.

\section{Busana Tari Bedana}

Segala macam benda yang melekat pada tubuh penari, selain berfungsi sebagai penutup tubuh, juga memperindah seseorang dalam tampilannya. Tata rias dan busana dalam seni tradisi kita masih memiliki fungsi yang sangat penting. Kehadirannya dalam sebuah pertunjukan tari, keduanya apakah tatarias atau tatabusana secara umum dapat memperkuat ekspresi, penokohan, serta keindahan. Selain itu ia juga dapat memberikan menggabarkan peristiwa di atas panggung tentang siapa, kapan, dan dimana peristiwa yang digambarkan dalam pertunjukan itu terjadi.

Begitu pula dalam kostum busana yang dikenakan dalam tari bedana disetiap provinsi memiliki ciri khas masing masing sesuai dengan karakter dan lingkungan yang bersangkutan. Di provinsi lampung busana tari bedana memiliki beberapa varian, namun sebagian besar busana tersebut hampir sama atau serupa. Busana tari bedana meliputi sebagai berikut:

a. Busana Tari Bedana Wanita

1. Penekan rambut

2. Belatung tebak/sanggul malam

3. Gaharu kembang goyang/Sual Kira

4. Kembang melati/Kembang melur

5. Subang Giwir /anting-anting

6. Buah jukum/Bulan Temanggal

7. Bulu Serattei/Bebiting 
8. Gelag Kano/ gelang Bibit

9. Kawai kurung

10.Tapis / Betuppal

b. Busana Tari Bedana pria

1. Kikat akinan/Peci sebagai ikat kepala

2. Kawai teluk belanga/ Belah Buluh

3. Kain bidak gantung/Betumpal sebatas lutut

4. Bulu sarattei/ Beibting

c. Pemakaian Busana Tari Bedana

Dalam pemakaian busana wanita terbilang cukup mudah dan tidak terikat oleh polapola atau syarat-syarat tertentu yang penting rapih, pantas dan serasi. Setelah wajah dirias, rambut dirapihkan dan sanggul malang dipasangkan, tusukan kembang melati yang ditata sedemikian rupa diatas sanggul supaya terlihat indah dan rapih. Ikatkan penekan rambut di tengah-tengah dahi kemudian tarik ke belakang dan ikatkan ujung kiri kanannya diantara kepala dengan sanggul lalu rapihkan kedua ujungnya. Pasangkan gaharu kembang goyang/ sual kira tepat di tengah kepala bagian belakang, sejajar dengan penekan rambut tadi. Usahakan gaharu ini menutup kedua ujung penekan, pakailah subang giwir/anting-antingnya pada kedua telinga kiri dan kanan.

Apabila bagian atas kepala sudah selesai dan rapih dilanjutkan dengan memakai kain tapis/Betupal. Ikatlah bagian pinggang dengan tali dengan kencang agar tidak melorot, ratakan ujung tapis bagian bawah sebatas mata kaki, jangan terlalu ke bawah atau terlalu tinggi karena akan mempengaruhi gerak tari. Pada bagian dada kenakan long torso, usahakan agar ikatan tapis pada bagian pinggang tertutup, kemudian memakai baju kurung, terakhir kenakanlah asesoris-asesorisnya seperti kalung buah jukum/bulan temanggal, bulu serattei/babitting dan gelang kano/bibit. Yang perlu diingat bagi penari Bedana wanita, tapis tidak boleh dipakai seperti gantung pada pria, selain kurang pantas dilihat juga tidak sesuai dengan adat ketimuran bangsa Indonesia.

Untuk pemakaian busana pria, sang penari mengenakan baju teluk belanga atau belah buluh, kemudian memakai kain bidak/ betumpel sebatas lutut. Pada bagian pinggang bagian atas ikatkan bulu serattei/bebiting. Setelah rapih dan kuat baru kita memakai ikat kepala/peci. Ada beberapa cara untuk mengikatkan ikat kepala pada penari, antara lain: Kelupak Taduk, Gulo Sekirik, Punai Meghem, Tanjak, Layar Tekember, Elang Bekekhang dan Elang Hinggap a. Cara memakai ikat kepala kelopak Taduk Kikat 
akkinan berbentuk segi empat, dilipat diagonal sehingga lipatannya membentuk sebuah segitiga. Pada garis diagonalnya dilipat-lipat selebar tiga jari tangan $( \pm 6 \mathrm{~cm})$ sehingga segitga besar tadi menjadi segitiga yang tinggi garis tengahnya $\pm 25 \mathrm{~cm}$, kemudian puncak dari segitiga letakkan di belakang kepala, dengan puncaknya kebawah. Kedua ujung kanan dan kiri dilingkarkan ke depan sampai di tengah dahi tepat di atas alis setengah hidung, belitkan sehingga ujung kanan menjadi sebelah kiri dan ujung kiri menjadi bagian sebelah kanan, tarik ke belakang dan ikatkan di belakang kepala. Sesudah itu puncak dari segitiga yang ke bawah tarik keduanya ke atas sehingga tegak, ujung segitiga bagian dalam dilipat seperti tadi kira-kira di atas lipatan yang terdahulu.

\section{A. Musik Tari Bedana}

Menurut Marwansyah mengatakan, bahwa: "musik dan tari adalah sebagai alat komunikasi melalui bunyi dan gerak bagi setiap insan pencinta dan pelaku seni." (Marwansyah, 1992: 8). Secara tradisional musik dan tari sangat erat hubungannya, keduanya saling membutuhkan, karena keduanya mempunyai sumber yang sama, yaitu dorongan dan naluri ritmis manusia. Dalam musik Tari Bedana terdapat bunyi atau suara untuk mengiringi tari dapat dihasilkan oleh penari itu sendiri, seperti tepuk tangan, hentakan kaki ataupun bunyi-bunyian yang dihasilkan oleh perlengkapan penari yang dipakai, bahkan ada kalanya menggunakan teriakan-teriakan vokal, hal ini menimbulkan kesan riang dalam pertunjukkan Tari Bedana. Tari Bedana memiliki beberapa ciri khas, antara lain: Lagu pengiring tari Lagu dalam tari Bedana merupakan keharusan,karena lagu yang dilantunkan dapat merupakan panduan untuk perubahan gerak atau komposisi.Biasanya lagu yang mengiringi tari Bedana bersifat gembira yang bersumber dari salawat nabi, sagata, adi- adi,wayak atau pantun seperti lagu penayuhan,lagu mata kipt,lagu bedana dan lain-lain.Hubungan antara penari dan pemusik pengiring tari sangat erat, sehingga antara gerak, komposisi dan musik tari dapat diatur sedemikian rupa, seperti tempo, suasana, gaya, dan bentuknya dapat ditata oleh penata tari dan penata musik.

Musik Tari Bedana menggunakan alat musik tradisional tumbuhnya dan keberadaaan alat musik di daerah Lampung sangat erat hubungannya dengan upacara adat, seperti:

1. Talo Balak

2. Kulintang Pekhing

3. Gambung Lunik

4. Karenceng

5. Serdam

6. Serdap dan berdah 
Untuk mengiringi musik tari Bedana masih digunakan alat musik tradisional yang sederhana walaupun tidak menutup kemungkinan dipakainya alat musik moderen sebagai musik tambahan atau sarana untuk menunjang, selama tidak mengurangi nilai dan ciri khas daerah Lampung. Alat musik pengiring tari Bedana yang lazim dipakai adalah: Alat musik Gambus Lunik, yaitu sebuah alat musik tradisional daerah Lampung yang dipetik, dawai berjumlah empat hingga menghasilkan nada yang dominan, yang biasanya mengiringi lagu- lagu tari bedana seperti lagu Selimpat, lagu penayuhan lagu bedana dan lain-lain.

Alat musik ini biasa dimainkan atau dipetik sekaligus membawakan lagu yang berirama Salimpat atau Bedana. Alat ini dibuat dari kayu nangka yang berdawai dengan urutan dibawah ini: a. Tali Kuint b. Tali Genda c. Tali Goro d. Tali Tala 2. Ketipung, yaitu alat musik yang biasanya digunakan untuk mengiringi tari Bedana dan lagu-lagu tradisional.

Alat musik berikutnya adalah Karenceng (Terbangan), yaitu alat musik yang dibuat dari kayu nangka yang fungsinya sama dengan ketipung atau lebih dominan alat musik ini sebagai pengiring arak-arakan. Selain itu Alat ini berfungsi sebagai gendang atau pengatur tempo dalam gerakan tari Bedana. Simbol notasi Karenceng atau Ketipung tang (pukulan bagian samping · dung (pukulan bagian tengah) · cang (untuk pukulan tahto/tahtim). Selanjutnya Alat musik pengiring tambahan biasanya dipakai Gong kecil bahkan untuk lebih semaraknya dapat pula dipakai alat-alat musik modern seperti: Biola, Accordian, dan lain-lain.

Alat-alat tersebut pada mulanya digunakan untuk sarana upacara adat atau tari yang berfungsi sebagai sarana adat. Penyajian musiknya belum menggunakan acuan penataan musik tertentu pada umumnya bersifat monoton dan belum ada suatu patokan yang menjadi pedoman penari secara naluri saja. Bentuk lagu ataupun tabuh yang disajikan pada umumnya berdiri sendiri, walaupun ada tabuh atau musik yang berkaitan itu hanya kebetulan secara naluri. Dengan perkembangan tekhnologi musik Tari Bedana di kolaborasikan dengan alat musik modern seperti biola, orgen, perkusi, dan drum alat band, sehingga menyajikan tarian dengan musik tari dengan suasana terasa yang lebih meriah memberikan kesan kegembiraan yang lebih terlihat jelas. 
AKSARA Jurnal Bahasa dan Sastra

Vol. 18, No. 2, Hal. 178 - 191, Oktober 2017

http://jurnal.fkip.unila.ac.id/index.php/aksara

\section{B. Ragam Gerak Tari Bedana}

a. Tahtim

Hitungan 1 kaki kanan melangkah ke depan Hitungan 2 kaki kiri melangkah ke depan Hitungan 3 kaki kanan melangkah ke depan, kaki kiri diangkat Hitungan 4 kaki kiri balik ke badan ke kiri Hitungan 5 langkah kaki kanan Hitungan 6 maju kaki kiri diikuti kaki kanan jinjit sebelah kiri Hitungan 7 maju kaki kanan sebelah kaki kiri langsung menarik jongkao (sumpah)

(Pada hitungan 1 melangkah setengah meloncat posisi badan tegap gerakan tangan mengayun berlawanan dengan gerak kaki, pandangan ke depan mengikuti arah gerakan kaki)

b. Humbak muloh

Hitungan 1 kaki kanan ke samping kanan Hitungan 2 kaki kiri ke samping kanan (mengikuti kaki kanan) Hitungan 3 kaki kanan kesamping kanan Hitungan 4 kaki kiri ayun ke depan Hitungan 5,6,7,8 kebalikan hitungan 1,2,3,4 (gerak tangan berkelai)

c. Gelek

Hitungan 1 ayun angkat kaki kanan Hitungan 2 langkah kaki kanan Hitungan 3 langkah kiri Hitungan 4 langkah kaki kanan Hitungan 5 mundur kaki kiri Hitungan 6 langkah samping kaki kanan ke kiri Hitungan 7 silang kaki kiri ke depan Hitungan 8 ayun kaki kanan ke depan

d. Ayun

Hitungan 1 langkah kaki kanan Hitungan 2 langkah kaki kiri Hitungan 3 langkah kanan Hitungan 4 angkat (ayun) kaki kiri (gerakan siku tangan seperti hendak menyikut)

e. Kesek injing

Hitungan 1 langkah kaki kanan Hitungan 2 langkah kaki kiri Hitungan 3 mengangkat kaki kanan diletakkan sebelah kanan kaki kiri jinjit (badan merendah)

Hitungan 4 mengayun kaki kanan ke samping kanan 30 derajat (tangan mengepal seperti hendak menyikut)

f. Kesek Gantung

Hitungan 1 langkah kaki kanan ke depan Hitungan 2 langkah kaki kiri ke depan Hitungan 3 ayun kaki kanan geser ke samping kanan 30 derajat Hitungan 4 tarik kaki kanan merapat kaki kiri (angkat)

(Gerak kaki kanan bisa dilakukan dengan kaki kiri atau sebaliknya gerakan siku tangan seperti hendak menyikut) 
AKSARA Jurnal Bahasa dan Sastra

Vol. 18, No. 2, Hal. 178 - 191, Oktober 2017

http://jurnal.fkip.unila.ac.id/index.php/aksara

g. Jimpang

Hitungan 1 langkah kaki kanan Hitungan 2 langkah kaki kiri Hitungan 3 mundur kaki kanan Hitungan 4 langkah kaki kiri ke kiri gerakan siku tangan seperti hendak menyikut Hitungan 5 langkah kaki kanan Hitungan 6 Putar kaki kiri ke samping kiri Hitungan 7 diikuti kaki kanan balik putar ke kanan (sembokh) Hitungan 8 angkat kaki kiri ke samping kiri kaki kanan dengan pasti kaki kiri jinjit (Gerak angan kimbang) h. Belitut

Hitungan 1 langkah kaki kanan silang ke kiri Hitungan 2 diikuti kaki kiri di belakang kaki kanan Hitungan 3 langkah kaki kanan silang ke kiri Hitungan 4 maju kaki kanan Hitungan 5 silang kaki kiri ke kanan putar badan Hitungan 6 mundur kaki kanan Hitungan 7 ayun kaki kiri ke depan

\section{REFERENSI}

Arikunto, Suharsimi. 1996. Prosedur Penelitian Suatu Pendekatan Praktik. Jakarta: Rineka Cipta.

Hadikusuma, Kunaryo. Munib, Achmad. Budiono. Suryono, Sawa. 1996. Pengantar Pendidikan. Semarang: IKIP Semarang Pres.

Hadi, Y. Sumandiyo. 2007. Kajian Tari Teks dan Konteks. Yogyakarta: Pustaka Book Publisher. 2007. Pendekatan Tari Nonliteral. Yogyakarta: Manthili.

Hawkins, Alma M. 1990. Creating Through Dance. Los Angeles : University Of California. Dialih bahasakan oleh Y. Sumandyo Hadi. Mencipta Lewat Tari. Yogyakarta: Institut Seni Indonesia Yogyakarta.

Nasution. 1995. Berbagai Pendekatan Dalam Proses Belajar dan Mengajar. Jakarta: Bumi Aksara.

Novrida, Nurhayati. 2004. Deskripsi Tari Melinting. Bandar Lampung: Taman Budaya.

Nurgiantoro, Burhan. 1988. Penilaian Dalam Pengajaran Bahasa dan Sastra. Yogyakarta: BPFE.

Nursantara, Yayat. 2007. Seni Budaya untuk SMA Kelas X. Jakarta: Erlangga

Robbin, Stephen P. 2007. Organizational Behavior $12^{\text {th }}$. New Jersey: Prentice Hall.

Soedarsono. 1992. Pengantar Apresiasi Seni. Jakarta: Balai Pustaka.

Sudjana. 2005. Metoda Statistika. Bandung: Tarsito.

Sugiyono. 2004. Metode Penelitian Bisnis. Cetakan keenam. Bandung: Alfabeta. 2006. Metode Penelitian Pendidikan, Pendekatan Kuantitatif, Kualitatif dan $R \& D$. Bandung: Alfabeta.

Tim MKDK. 1996. Belajar dan Pembelajaran. Semarang: IKIP Semarang. Usman, Husaini. Setiady Akbar, Purnomo. 2003. Pengantar Statistika. Jakarta: Bumi Aksara. 